- практичний, основне завдання якого - формування підприємницького мислення;

- прикладний, покликаний залучати здобувачів освіти до соціальних практик підприємництва.

Розроблена авторська структурно-логічна схема може стати основою внутрішньо узгодженої системи впливів, спрямованих на формування підприємницької культури майбутніх бакалаврів фізичної культури та спорту. Найважливішим чинником успішної реалізації цього процесу визначено дотримання принципу варіативності, зокрема можливості вибору здобувачем освіти власної освітньої траєкторії.

Подальші дослідження у даному напрямі плануємо присвятити перевірці отриманих на практиці результатів.

\section{СПИСОК ВИКОРИСТАНОЇ ЛІТЕРАТУРИ}

1. Буренко М. С. Формування фаховий компетенцій майбутніх тренерів-викладачів у процесі вивчення циклу професійно-орієнтованих дисциплін : дис. ... канд. пед. наук : 13.00.04. Запоріжжя, 2012. 224 с.

2. Мазін В. М. Теоретико-методичні засади організації виховного процесу у дитячо-юнацьких спортивних школах : дис. ... док. пед. наук : 13.00.07. Старобільськ, 2016. 512 с.

3. Освітньо-професійна програма «Фізична культура і спорт» першого (бакалаврського) рівня вищої освіти. Галузь знань 01 «Освіта. Педагогіка». Спеціальність 017 «Фізична культура і спорт». Київ : Відкритий міжнародний університет розвитку людини «Україна», 2019. 21 с.

4. Освітньо-професійна програма «Фізична культура і спорт» першого (бакалаврського) рівня вищої освіти. Галузь знань 01 «Освіта. Педагогіка».
Спеціальність 017 «Фізична культура і спорт». Херсон : Херсонський державний університет, 2019. 22 с.

5. Освітньо-професійна програма «Фізична культура і спорт» першого (бакалаврського) рівня вищої освіти. Галузь знань 01 «Освіта. Педагогіка». Спеціальність 017 «Фізична культура і спорт». Дніпро : Придніпровська державна академія фізичної культури і спорту, 2018. 27 с.

6. Освітньо-професійна програма «Фізична культура і спорт» першого (бакалаврського) рівня вищої освіти. Галузь знань 01 «Освіта. Педагогіка». Спеціальність 017 «Фізична культура і спорт». Тернопіль : Тернопільський національний педагогічний університет імені Володимира Гнатюка, 2017. 19 с.

7. Освітньо-професійна програма «Фізичне виховання» здобуття першого (бакалаврського) рівня вищої освіти. Галузь знань 01 «Освіта. Педагогіка». Спеціальність 017 «Фізична культура і спорт». Запоріжжя : НУ «Запорізька політехніка», 2019. 11 с.

8. Перепльотчиков Д. О. Підготовка майбутніх фахівців фізичного освітнього процесу і спорту до організації діяльності ЗВО : дис. ... канд. пед. наук : 13.00.04. Запоріжжя, 2011. 222 с.

9. Пономарьов В. О. Формування професійно-педагогічної компетентності майбутнього тренера 3 атлетичної гімнастики у процесі фахової підготовки : дис. ... канд. пед. наук : спец. 13.00.04. Запоріжжя, 2010. $20 \mathrm{c}$.

10. Тонне О. Ш. Умови організації самостійної пізнавальної діяльності вчителів у процесі підвищення кваліфікації. Вісник післядипломної освіти: збірник наукових пращь. Серія «Педагогічні науки». 2017. № 5 (34). C. 126-136.

Дата надходження до редакиії: 15.102020 p.

\section{УДК 378.014.61:615.8}

DOI: 10.37026/2520-6427-2020-104-4-136-140

\section{Олег ЧЕПУРКА,}

здобувач ступеня $P h D$

кафедри теорії і методики виховання

Рівненського державного гуманітарного університету

\title{
СТВОРЕННЯ ІННОВАЦІЙНОГО СУБ'ЄКТ-СУБ'ЄКТНОГО СЕРЕДОВИЩА ДЛЯ ПІДГОТОВКИ МАЙБУТНІХ БАКАЛАВРІВ ФІЗИЧНОЇ ТЕРАПІї В ЗАКЛАДАХ ВИЩОЇ ОСВІТИ
}

У статті виокремлено й схарактеризовано сучасне інноваційне суб'єкт-суб'єктне середовище для підготовки майбутніх бакалаврів фізичної терапї в закладах вищої освіти. У сучасному освітньому середовищі спостерігається зміна саме парадигми вищчӧ освіти, яка пов'язана з пошуком таких педагогічних умов $i$ засобів, які б забезпечували ефективну підготовку майбутніх бакалаврів фізичної терапії до реалій ринку праці, що постійно змінюється. Досягнення конкурентоспроможної якості національної освіти в контексті иивілізаційних змін сьогодення стає пріоритетом модернізації освіти України. У ході діалогового навчання майбутніх бакалаврів фізичної терапії навчають критично мислити, 
вирішувати складні проблеми на основі аналізу обставин і відповідної інформації, зважувати альтернативні думки, приймати продумані рішення, брати участь у дискусіях, спілкуватися з іншими людьми. До інноваційних форм і методів фахової підготовки майбутніх бакалаврів фізичної терапії нами віднесено: творчі завдання; робота в малих групах; навчальні ігри (рольові ігри, імітаиії, ділові ігри); соиіальні проєкти; інтерактивні лекиії; робота з наочними посібниками, відео- $і$ аудіоматеріалами. Окремо розкрито умови застосування практичних інноваційних форм суб'єкт-суб'єктної взаємодії майбутніх фахівиів фізичної терапї в освітньо-виховному прочесі закладів вищої освіти. Виокремлено й розкрито такі інновачійні методи, як: евристична бесіда, дискусія, «мозкова атака», «круглий стіл», ділова гра, кейс-метод, а також конкурси практичних робіт із подальшим їх обговоренням. Доведено, щио проведення ділових ігор не лише забезпечує ефективне формування професійно значущих якостей майбутніх бакалаврів фізичної терапії, а й розширює їхні уявлення про сутність обраної професї.

Ключові слова: фахова підготовка, заклад вищмої освіти, майбутні бакалаври фізичної терапї, інноваційні методи, інновачійне середовище, суб 'єкт-суб'єктна взаємодія.

The article presents and characterizes modern innovative subject-subject environment in higher educational establishments for training of future bachelors in physiotherapy. It is mentioned about paradigm change in higher education in modern educational environment, that is connected with the quest of pedagogical conditions and means by which effective training of future bachelors in physiotherapy for the realities of changing labor market will be provided. The priority of modernization of education in Ukraine is to achieve quality competitiveness of national education in the context of present civilizational changes. During dialogue training future bachelors in physiotherapy learn to think critically, to solve difficult problems through analysis of circumstances and appropriate information, to take into consideration alternative ideas, to make thought-out decisions, to take part in discussions, to communicate with other people. The author considers innovative forms and methods of professional training of future bachelors in physiotherapy such as: creative tasks, work in small groups; educational games (role-playing, imitation, business games); social projects; interactive lectures, work with visual aid, video and audio materials. The article also shows conditions of practical application of innovative forms of subject-subject interaction in the process of training of future bachelors in physiotherapy in higher educational establishments. The author distinguishes and reveals the following innovative methods: heuristic conversation, discussion, brain storm, round table, business games, case method, contests of practical works and discussions. It is proven that using of business simulation games both provides effective development of professional qualities of future bachelors in physiotherapy and extend the idea of the essence of the chosen profession.

Key words: professional training, higher educational establishment, future bachelors in physiotherapy, innovative methods, innovative environment, subject-subject interaction.
Постановка проблеми. Розвиток національної системи вищої освіти, входження ï до європейського і світового освітнього простору детермінують процеси формування життєво важливих і професійних ціннісних орієнтацій майбутніх бакалаврів фізичної терапії, що обумовлює появу інноваційних форм, методів і методик організації освітньо-виховного процесу в закладах вищої освіти. У цьому контексті В. Кремень наголошує, що «...нові освітні реалії визначають нові вимоги щодо розвитку вищої освіти, оскільки в усьому світі вона сьогодні перестає бути просто способом підготовки фахівців у певній сфері діяльності, а набуває суттєвого фахового, культурологічного спрямування» $[1$, с. 6$]$.

Аналіз наукових досліджень і публікацій. Одним із пріоритетних напрямів модернізації сучасної системи вищої освіти у сфері фізичної терапії в Україні $є$ Постанова Кабінету Міністрів України «Про затвердження переліку галузей знань і спеціальностей, за якими здійснюється підготовка здобувачів вищої освіти» від 29.04.2015 р. № 266. Згідно з цим документом спеціальність «Фізична реабілітація» була перенесена із галузі знань 0102 «Фізичне виховання, спорт та здоров'я людини» до галузі знань 22 «Охорона здоров'я» під номером 227 «Фізична реабілітація», що визначило новий напрям іiі розвитку в структурі підготовки фахівців галузі «Охорона здоров'я» в Україні. У подальшому постановою КМУ від 01.02.2017 p. № 53 «Про внесення змін до постанови від 29.04.2015 p. № 266 назву спеціальності 227 «Фізична реабілітація» галузі знань 22 «Охорона здоров'я» викладено в такій редакції - 227 «Фізична терапія, ерготерапія» галузі знань 22 «Охорона здоров'я».

Проблемі обгрунтування і розроблення концептуальних засад сучасної системи національної освіти, філософсько-культурологічних аспектів соціальної природи особистості присвячено дослідження В. Кременя, В. Крисаченка, П. Сауха, О. Сухомлинської, Г. Філіпчука та інших; проблемі розбудови вищої школи в системі неперервної освіти наукові дослідження В. Жураковського та I. Федорова; визначенню пріоритетних напрямів модернізації сфери фізичної терапії здійснено у наукових працях О. Муравйова, Т. Бугеря В. Андрущенка [2, с. 54-63], Н. Ничкало [3, с. 105-110] та ін.

Iз позицій сьогодення перед вищою школою, на думку П. Саламатова, «...набуло визнання важливе завдання переходу до підготовки майбутніх фахівців, які могли б у своїй професійній діяльності поєднувати глибокі фундаментальні теоретичні знання і практичну підготовку із постійно зростаючими вимогами інформаційного суспільства» [4, с. 69].

Метою статті $є$ виокремлення й характеристика теоретико-прикладних засад створення інноваційного суб'єкт-суб'єктного середовища і взаємодії для підготовки майбутніх бакалаврів фізичної терапії у закладах вищої освіти.

Виклад основного матеріалу. У контексті зазначеного вище Ю. Лянной та Н. Кукса зауважують, що в «...сучасній освітній системі спостерігається зміна парадигми вищої фізкультурної освіти, яка пов'язана iз пошуком таких педагогічних умов і засобів, які б забезпечували успішну підготовку майбутніх бакалаврів фізичної терапії до високого темпу життя, peaлій ринку праці, що постійно змінюється» [5, с. 318]. 
У продовження цієї думки Н. Бєлікова актуалізує увагу на тому, що «....сучасні наука й освіта, створюючи і забезпечуючи сприятливі умови для індивідуального розвитку людини, покликані готувати для ринку праці конкурентоспроможного фахівця, здатного свідомо й ефективно функціонувати в умовах високотехнологічного інформаційного суспільства» [6, с. 9-14].

Схожу думку висловлює й В. Кремень, наголошуючи на тому, що «досягнення конкурентоспроможної якості національної освіти, в контексті цивілізаційних змін, в умовах сьогодення, стає пріоритетом модернізації освіти України» [7, с. 22].

У зв'язку з цим змістом компетентностей дисципліни «Теорія здоров'я та здорового способу життя» $\epsilon$ здатність майбутніх бакалаврів фізичної терапії аналізувати здоров'я як системну категорію та визначати перспективні напрями збереження здоров'я як власного, так і оточуючих. Вивчення майбутніми фахівцями із фізичної реабілітації такого навчального матеріалу сприяє: засвоєнню теоретичних знань, формуванню цілісного уявлення про здоров'я людини та іiї фізичну, психологічну, соціальну, духовну складові, а також навичок здорового способу життя і практичних умінь щодо поліпшення стану фізичного здоров'я осіб; усвідомленню сутності таких понять, як «загальна теорія здоров'я», «здоров'я», «різні форми здоров'я», «фізична терапія» тощо; дослідженню чинників, що не лише формують здоров'я людини, а й негативно впливають на нього. Уміти надавати рекомендації щодо: профілактики та принципів боротьби зі шкідливими звичками; профілактики та усунення наслідків психоемоційного стресу; ведення здорового способу життя; уникнення негативного впливу перевтоми, стану гіподинамії, ризиків травматизму.

Таким чином, підготовка майбутніх бакалаврів фізичної терапії до суб'єкт-суб'єктної взаємодії у професійній діяльності передбачає упровадження в освітньо-виховний процес закладів вищої освіти інноваційного змісту, форм, методів та методик. Їх застосування, на думку І. Гревцевої, «...передбачає організацію і розвиток діалогового спілкування, яке сприяє налагодженню взаєморозуміння, взаємодії та спільному вирішенню загальних, але вагомих для кожного учасника завдань. У ході діалогової взаємодії майбутні бакалаври фізичної терапії навчаються критично мислити, вирішувати складні проблеми на основі аналізу обставин і відповідної інформації, зважувати альтернативні думки, приймати продумані рішення, брати участь у дискусіях, спілкуватися 3 оточуючими» [8].

Водночас I. Гревцева актуалізує увагу на ефективності застосування інноваційних форм і методик «...організації індивідуальної, парної і групової творчої роботи майбутніх бакалаврів фізичної терапії завдяки упровадженню в освітньо-виховний процес закладів вищої освіти дослідницьких проєктів, рольових та мозкових атак тощо [8, с. 16].

У цьому контексті, як засвідчили результати нашого дослідження, до інноваційних форм і методів професійної підготовки майбутніх бакалаврів фізичної терапії нами віднесено: творчі завдання, робота в малих групах; навчальні ігри (рольові, імітації, ділові ігри); соціальні проєкти; інтерактивні лекції, робота з наочними посібниками, відео- та аудіоматеріалами. Окреме місце належить застосуванню практичних інноваційних форм суб'єкт-суб'єктної взаємодії майбутніх бакалаврів фізичної терапії в освітньо-виховному процесі закладів вищої освіти, як-от: «студент у ролі викладача»; навчання «рівний рівному»; обговорення дискусійних питань; проєктні техніки; «зміни позицію», «карусель», «дискусія», «дерево рішень»; дебати; симпозіум; «круглий стіл» та ін. У цьому контексті акцентуємо увагу на тому, що сутність інноваційного навчання полягає в тому, що освітній процес закладу вищої освіти організований таким чином, що забезпечує участь майбутніх бакалаврів фізичної терапії не лише в процесах пізнання і засвоєння нового навчального матеріалу, але й створює умови для особистої рефлексії з приводу того, що вони уже знають і вміють, та що, на їх погляд, важливо ще вивчити й чому навчитися. Продовжуючи цю думку можемо виокремити такі інноваційні методи, як: евристична бесіда, дискусія, мозкова атака, «круглий стіл», ділова гра, кейс-метод, конкурси практичних робіт із подальшим їх обговоренням.

Схожу за своїм змістом думку висловлює А. Гриб, який доводить, що застосування інноваційних методів навчання передбачає таку логіку та послідовність навчальної діяльності: мотивація - формування нового досвіду - його усвідомлення через застосування рефлексія. У цьому контексті інноваційні методи й методики включають ігрові та неігрові форми навчання. Саме до ігрових методів дослідник відносить: ігри, навчально-ділові ігри, (операційні та імітаційні); дослідницькі роботи; кейс-методи; проєкти; ситуації-ілюстрації, аналіз ситуацій-проблем; тренінги; дебати, диспути, дискусію («круглий стіл», проблемна дискусія, експрес-дискусія, «акваріум», «ліберальний клуб», текстова дискусія) [9, с. 25].

Необхідно відзначити, що зазначені вище інноваційні методи організації навчання майбутніх бакалаврів фізичної терапії забезпечують ефективне формування ціннісних ставлень до майбутньої професії, посилюють мотивацію щодо іiі здобуття, підвищує творчу активність.

На думку Е. Макарової, розвиток творчої активності майбутніх бакалаврів фізичної терапії в освітньо-виховному процесі закладів вищої освіти передбачає такі її види:

1. Інтелектуальна взаємодія майбутніх фахівців і основних предметів навчання за фахом (унаслідок чого змінюється рівень їхньої підготовки та інтелектуальний рівень).

2. Суб'єкт-суб' єктна взаємодія майбутнього фахівця і викладача у освітньо-виховному процесі.

3. Взаємодія майбутніх фахівців між собою в освітньо-виховному процесі як членів мультидисциплінарної групи (команди) [10].

Ураховуючи те, що процес інтенсивної взаємодії майбутніх бакалаврів фізичної терапії у мультидисциплінарній групі забезпечує різностороннє вивчення пацієнта, це сприяє не тільки формуванню їхньої професійної компетентності, а й особистісному зростанню і розвитку гуманного ставлення до людей, які потребують їхньої фахової допомоги. Необхідно відзначити, що у майбутніх бакалаврів фізичної терапії відбувається не тільки накопичення системних знань і професійного досвіду взаємодії з особами, які потребують їхньої уваги і допомоги, а й формується бачення клінічних проявів різних захворювань. Отже, можемо стверджувати, що сформована емпатія у процесі реалізації мультидисциплінарного підходу призводить до встановлення толерантних суб'єкт-суб'єктних стосунків і тісної взаємодії між учасниками мультидисциплінарної групи і підвищення соціальної адаптації терапевтичних заходів. 
У такому контексті особлива роль належить саме закладам вищої освіти, які, на думку А. Карпової, в сучасних інноваційних освітніх процесах на рівні держави забезпечують «...не тільки постачання на технологічні ринки науково-дослідної продукції, а й виховання фахівців інноваційного типу, які володіють компетенціями, що сприяють переходу від досліджень до розробок із подальшою їх комерціалізацією» [11, с. 38].

Результати наших досліджень засвідчили, що застосування освітніх інновацій у професійній підготовці майбутніх бакалаврів фізичної терапії, оволодіння ними обраною професією «...здійснюється нині переважно в контекстному навчанні, що являє собою процес динамічного руху майбутнього фахівця від навчальної діяльності академічного типу через квазіпрофесійну і навчально-професійну діяльність до власне професійної діяльності» [12, с. 56].

У зв'язку з цим А. Вербицький стверджує, що в процесах оволодіння професією майбутніми фахівцями $є$ три базові форми їхньої навчально-пізнавальної творчої діяльності. До базових форм він відносить навчальну діяльність академічного типу, класичним прикладом якої є інформаційна лекція, де головним чином відбувається суб'єкт-суб'єктна взаємодія ії̈ учасників. Сутність останньої полягає в передачі інформації викладачем і іiі засвоєння майбутніми фахівцями. Однак, продовжуючи далі, вчений зазначає, що під час застосування проблемної лекції або семінару-дискусії розкриваються предметний i соціальний контексти майбутньої професійної діяльності, моделюються дії фахівців, які обговорюють теоретичні, а інколи й суперечливі за своєю сутністю питання і нагальні проблеми. У межах квазіпрофесійної діяльності, за допомогою якої в аудиторних умовах виокремлюються і моделюються «...умови, зміст і структура, спрямування майбутньої професійної діяльності, що має незаперечну значущість у процесах навчально-професійної практичної діяльності, завдяки чому майбутні бакалаври фізичної терапії здійснюють реальну науково-дослідну роботу (магістерська, дипломна роботи) або набувають практичних професійних умінь i навичок (виробнича практика). Саме на цьому етапі професійної підготовки майбутніх бакалаврів фізичної терапії завершується процес трансформації навчальної діяльності у професійну [14, с. 48; 13, с. 37-41].

Отже, можемо зробити висновок, що у процесах квазіпрофесійної діяльності майбутніх бакалаврів фізичної терапії ефективним $\epsilon$ «...застосування методу проєктів, у ході виконання яких у них формуються соціальні уявлення про значення своєї майбутньої професії, набуваються нові знання й активізується критичне мислення, виробляється поведінка і вчинки, що відповідають нормам суспільної моралі» [14, с. 240].

Саме у процесах поступового переходу від однієї форми навчальної, практичної, проєктної чи творчої діяльності до іншої майбутні бакалаври фізичної терапії практикуються у застосуванні набутих фахових знань, умінь та навичок, набувають реального досвіду майбутньої професійної діяльності, засвоюють професійні норми і цінності, поступово «входять» у майбутню професію. Отже, поступовий перехід майбутніх бакалаврів фізичної терапії від навчальної до квазіпрофесійної діяльності, а в подальшому до навчально-професійної, характеризує основні етапи трансформації навчальної діяльності у професійну, забезпечуючи таким чином сприятливі умови для ефективного засвоєння нових системних професійних знань, формування важливих умінь та ціннісних орієнтацій. Підтвердженням правильності нашого висновку є позиція С. Тихолаза, який акцентує увагу на тому, що «...організація навчально процесу в закладах вищої освіти повинна узгоджуватися 3 динамікою розвитку професії майбутнього фахівця та врахуванням його індивідуальних можливостей, що має забезпечити чітку професійну спрямованість його індивідуальної діяльності» [15, с. 165-169].

Досліджуючи проблему професійної підготовки майбутніх бакалаврів фізичної терапії до суб'єкт-суб'єктної взаємодії в інноваційному середовищі закладів вищої освіти, ми дійшли висновку, що одним із теоретико-прикладних напрямів іï ефективного розв'язання $є$ застосування такого інноваційного методу, як ділова гра. Саме цей метод, як свідчать результати дослідження, має значний потенціал у підготовці майбутніх бакалаврів фізичної терапії в освітньому процесі закладів вищої освіти. За допомогою методу ділової гри можливо вирішити такі завдання, як моделювання процесу майбутньої професійної діяльності та сприяння розвитку умінь творчої колективної роботи.

У даному контексті ділову (рольову) гру ми розглядаємо як метод навчання, під час якого відбувається імітація та проєктування спрощеного відтворення реальної ситуації із професійної діяльності майбутніх бакалаврів фізичної терапії. Завдяки діловій грі їхнє навчання відбувається в процесі спільної суб'єкт-суб'єктної діяльності. За цих умов кожен вирішує своє індивідуальне завдання відповідно до своєї ролі та обов'язків у межах проведення такої гри. Отже, можемо констатувати, що ділові ігри у фаховій підготовці майбутніх бакалаврів фізичної терапії в закладах вищої освіти є ефективним педагогічним засобом, який інтенсифікує їхню навчальну діяльність на певному етапі, проєктуючи управлінські, економічні, психологічні та педагогічні ситуації, сприяє їхньому аналізу і виробленню оптимальної діяльності у подальшій навчальній діяльності.

Як засвідчили результати нашого дослідження, основою розробки ділової гри у фаховій підготовці майбутніх бакалаврів фізичної терапії $є$ створення ігрової (імітаційної) ситуації, що розкриває певні реальні події їхньої майбутньої професійної діяльності. Саме тому до складових ділової гри нами віднесено: іiі загальну мету і конкретні цілі; комплектування груп і розподіл учасників відповідно до обраних ролей; ознайомлення майбутніх бакалаврів фізичної терапії зі сценарієм, правилами гри та розробленими ситуаціями; усвідомлення ними змісту діяльності за обраними ролями; проведення гри; визначення кращих гравців; узагальнення результатів та аналіз гри.

Одним із найскладніших етапів розроблення ділової гри є вибір і характеристика об'єкта імітації та розроблення сценарію гри. Так, на практичному занятті $з$ дисципліни «Фізична реабілітація» проводилася ділова гра з теми «Місце і роль майбутнього бакалавра фізичної терапії у мультидисциплінарній групі». Відповідно до мети проведення такої гри було заплановано виконання майбутніми бакалаврами певних професійних дій. Наприклад, одні виконували роль лікаря-травматолога, інші - фахівця із фізичної терапії, медичної сестри, психолога, ерготерапевта тощо. У ході проведення ділової гри ми наголошували студентів на те, що травмована людина має бути готова 
до довготривалого відновлення функціональної стабільності ушкодженої ділянки власного тіла. У ході дискусії із майбутніми бакалаврами фізичної терапії, які виконували ролі лікаря-травматолога, фахівця фізичної терапії чи ерготерапевта, про організацію та проведення періодів відновлення хворих, вони самостійно чи за допомоги викладача вибудовували логічний ланцюжок реабілітаційних заходів, що мали забезпечити відновлення тимчасово втрачених функцій $з$ урахуванням важкості травми, індивідуальних особливостей, психоемоційного стану пацієнта.

Висновки. У процесі обговорення результатів проведеної ділової гри майбутні бакалаври фізичної терапії дійшли висновку, що кожен із них у межах мультидисциплінарної групи, залежно від свого професійного фаху, має виконувати визначені професійні діï, спрямовані на відновлення втрачених людиною функцій. Таким чином, вважаємо, що проведення ділової гри забезпечило ефективне формування професійно значущих якостей майбутніх бакалаврів фізичної терапії, а також розширило їхні уявлення про сутність обраної професії.

Означена стаття не вичерпує сутності досліджуваної проблеми, а є лише частковим підходом до ії вирішення. Особливої уваги заслуговують питання формування ціннісних орієнтацій, важливих професійних компетентностей, відповідального ставлення до засвоєння фахових дисциплін у процесі фахової підготовки майбутніх бакалаврів фізичної терапії.

\section{СПИСОК ВИКОРИСТАНОЇ ЛІТЕРАТУРИ}

1. Кремень В. Г. Проблеми якості української освіти в контексті сучасних цивілізаційних змін. Украӥнський педагогічний журнал. 2015. № 1. С. 8-15.

2. Андрущенко В. П., Бондар В. І. Модернізація педагогічної освіти в контексті викликів XXI століття. Свропейські педагогічні студї. 2015. Вип. 5/6. С. 54-63.

3. Ничкало Н. Г. Теоретико-методологічні проблеми реформування професійно-технічної освіти. Педагогіка і психологія. 1997. № 3. С. 105-110.

4. Саламатов П. В. Професійна підготовка майбутніх учителів з фізичної культури до навчання плавання дітей в оздоровчому таборі. Науковий вісник Південноукраӥнського начіонального педагогічного університету імені К. Д. Уиинського. Педагогічні науки. 2016. № 2. С. 69-73.
5. Лянной Ю. Створення реабілітаційної системи для спортсменів в Україні та підготовка фізичних реабілітологів для іiі функціонування. Молода спортивна наука Украӥни : зб. наук. пр. з галузі фізичної культури та спорту : в 4 т. Львів : НВФ «Українські технології», 2006. Вип. 10. Т. 3.496 с.

6. Бєлікова Н. О. Сучасний погляд на перспективи модернізації вищої фізкультурної освіти. Науковий часопис НПУ імені М.П. Драгоманова. 2013. Вип. 12 (39). C. 9-14.

7. Кремень В. Модернізація освіти - важливий чинник соціального, економічного і політичного розвитку України. Вісник Національної академії наук Украӥни. 2001. № 3. С. 22-25.

8. Гревцева И. В. Применение интерактивных методов обучения в образовательном процессе вуза. URL: http://lfostu.ucoz.ru/publ/innovacionnye podkhody_i_tekhnoIogii/primenenie_innovacionnykh_metodov_obuchenija_dlja_realizacii_kompetentnost-

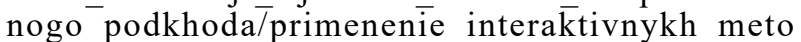
dov_obuchenija_v_obrazovatelnom_processe_vuza/ 29-1-0-284 (дата звернення: 12.09.2020).

9. Гриб В. А. Нові інноваційні технології та шляхи поліпшення навчального процесу зі спеціальності «неврологія». Медична освіта. 2013. № 1. С. 24-27.

10. Плаксина И. В. Интерактивные технологии в обучении и воспитании : метод. пособие / Владим. гос. ун-т им. А. Г. и Н. Г. Столетовых. Владимир : Изд-во ВлГУ, 2014. 163 с.

11. Макарова Е. Л. Использование интерактивных форм обучения для повышения эффективности образовательного процесса. URL: http://www.smtutco. $\mathrm{rn} / \mathrm{en} /$ interac/tive-forms-of/-learning (дата звернення: 05.08.2020).

12. Карпов А. О. Открытые инновации и высшее образование. Москва : Высшее образование. 2010. № 3. C. 37-41.

13. Вербицкий А. Активное обучение в высшей школе: контекстный подход. Москва : Высшая школа, 1991. 204 c.

14. Тихолаз С. І. Контекстний підхід до організації навчального процесу як умова розвитку професійної спрямованості студентів медичного університету. 3бірник наукових праць Хмельницького інституту соиіальних технологій Університету «Украӥна». 2011. № 4. C. 165-169.

Дата надходження до редакиіï: 20.11.2020 p. 